İş ve İnsan Dergisi I The Journal of Human and Work

Y1l | Year: Ekim | October 2016

Cilt-Say1 | Volume-Issue:3(2)

ss I pp: $109-118$

doi: 10.18394/iid.75792

e-ISSN 2148-967X

http://dergipark.ulakbim.gov.tr/iid/

Araştırma Makalesi

\title{
İş Yerinde Dikkat Eksikliği ve Hiperaktivite Bozukluğuna (DEHB) Yönelik Bir Araştırma
}

\section{A Research on Attention-Deficit and Hyperactivity Disorder at the Work Place}

\author{
Nuray Mercan* \\ Dumlupinar \\ Üniversitesi
}

\section{MAKALE BİLGİSİ}

Anahtar Kelimeler:

Dikkat Eksikliği.

Hiperaktivite Bozukluğu, $\dot{I}_{S}$

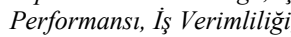

Kariyer Gelişimi

\section{Tarihler :}

Geliş 27 Haziran 2015

Düzeltme geliş 24 Temmuz

2016

Kabul 27 Temmuz 2016

\author{
Özlem Çetinkaya \\ Bozkurt \\ Mehmet Akif Ersoy \\ Üniversitesi
}

\author{
Emine Oyur \\ Dumlupinar \\ Üniversitesi
}

\author{
Ceren Giderler \\ Dumlupinar \\ Üniversitesi
}

ÖZ

Dikkat eksikliği ve hiperaktivite bozukluğu (DEHB) yaygınlı̆̆ yaklaşık olarak çocuklukta \% 8, ergenlikte \% 6 ve erişkinlikte \% 4 olarak bildirilmektedir. DEHB, kişilerde ișe odaklanamamaya yol açmakta bu da kariyerde ilerlemeye engel olabilmektedir. DEHB olan kişiler birçok işe aynı anda başlamakta ve birçoğunu bitirememektedirler. Bu araştırmada, işyerinde dikkat eksikliği ve hiperaktivite düzeyi belirlenerek bazı demografik değişkenlerle arasindaki ilişsi incelenmiștir. Araștırmada Dünya Sağlık Örgütü’nün "Erișkin Dikkat Eksikliği Hiperaktivite Bozukluğu Kendi Bildirim Ölçeği (ASRS)" kullanılmıştır. Ölçeğin Türkçe formunun geçerlilik ve güvenilirlik çalıșması Doğan ve arkadaşları (2009) tarafindan yapılmıștır. Araștırmanın evrenini internet ortamında ulaşılan çalışanlar oluşturmaktadır. Örneklem ise, bu çalışanlar arasından rastgele seçilen 500 kișidir. Araștırma sonucunda, çalıșanlarda \%2,4 oranında DEHB saptanmıştır. Farkllliklara yönelik yapılan, T testi analizi sonucunda; DEHB olan yönetici ve çalışanlar arasında anlamlı bir farklllık görülmemiştir.

\section{ARTICLE INFO}

\section{Keywords:}

Attention Deficit,

Hyperactivity, Business

Performance, Business

Productivity, Career

Development

Article history:

Received 27 June 2015

Received in revised form 24

July 2016

Accepted27 July 2016

\begin{abstract}
A B S T R A C T
The prevalence of Attention-Deficit and Hyperactivity Disorder (ADHD) is reported as $8 \%$ in childhood, $6 \%$ in adolescence and $4 \%$ in adulthood approximately. ADHD leads to inability to focus on work for people and may be an obstacle to progress in people's careers. Individuals with Attention-Deficit and Hyperactivity Disorder may start a lot of work at the same time and unable to finish the most of it. In this study Attention-Deficit and Hyperactivity Disorder levels have been determined at work places and its relationships with several demographic variables have been analyzed. In this study, "Self-Report Scale of Attention Deficit Hyperactivity Disorder in Adults (ASRS)" by WHO (World Health Organization) has been utilized. The validity and reliability study of Turkish form was done by Dogan et al. (2009). The population of the research is the employees reached on the internet. The sample in the study consists of randomly selected 500 people. In the end of the study, it has been seen that $2.4 \%$ of the employees have ADH). The T-Test analysis indicates that no significant difference has been found between managers and employees for ADHD.
\end{abstract}

* İletişim Kurulacak Yazar: Nuray Mercan, Dumlupınar Üniversitesi, Tavşanlı Turizm İşletmeciliği ve Otelcilik Yüksekokulu, Kütahya, Türkiye. E-posta: nuraymercan26@gmail.com 


\section{GİRIŞ}

Dikkat eksikliği ve hiperaktivite bozukluğu (DEHB) kalıcı ve sürekli olan dikkat süresinin kısalığı, davranışları kontrol etmeye ve ertelemeye yönelik özdenetim eksikliğinden kaynaklanan, davranışlarda ve düşünce sisteminde meydana gelen dürtüsellik ve huzursuzluk olarak tanımlanmaktadır. DEHB olan bireylerde bir işe başlayamama, iş yerinde verimsizlik ve kötü zaman yönetimi, çok sayıda işe başlanmasına rağmen birçoğunu bitirememe, bir toplantı boyunca oturamama, stresle baş edememe ve öfke atakları, aklına ilk geleni söyleme eğilimi, randevularını veya yapmak zorunda olduğu işleri unutma, birçok basamağ içeren işleri yapmakta zorlanma, bir işe ya da projeye başlamakta ve bitirmekte zorlanma, oyalanma, erteleme eğiliminde olma, bilgilere öncelik vermede zorlanma, çabuk sıkılma ve sabırsızlık, sıklıkla yerinde duramama, huzursuzluk hissi yaşama, zamanını verimli kullanamama, evde ve iş yerinde eşyalarını bulamama, yanlış yere koyma gibi bazı davranışlar gözlenmektedir (Güçlü \& Erkıran, 2005).

Örgüt içerisinde, DEHB'li bireylerin durumu ele alındığında, bu bireylerin, işgücü devir oranının yüksekliği, işe devamsızlık/işe geç gelme davranışları ve örgütsel bağlılık oluşumunda yaşanan güçlükler mikro açıdan bakıldığında örgütler için maliyet unsuru haline gelirken, makro açıdan bakıldığında ise ülke ekonomisine ilişkin olarak insan kaynağının israfi ile sonuçlanmaktadır (Altınay \& Alamur,2015).

Araştırmada öncelikle kavramsal çerçeve anlatılacak daha sonra araştırma bulgu ve analiz yorumları yazılarak sonuçlandırılacaktır.

\section{KAVRAMSAL ÇERÇEVE}

DEHB, 1900'lü yılların başından beri tanınan bir sendromdur ve dikkat dağınıklığı, aşırı hareketlilik, dürtüsel davranışları içeren bir takım bozuklukları kapsamaktadır. Bireyin sosyal yaşamında, ilişkilerinde, eğitim ve iş yaşamında odaklanmayı engellediğinden dolayı sorunlar oluşturmaktadır (Brown, 2009: 9). DEHB tanıs1 olan bireyler akademik, sosyal ve psikolojik zorluklarla karşılaşma riskini taşımaktadırlar (Weyandt \& Dupaul, 2008). DEHB'li yetişkinlerde yapılan araştırmalar bize sosyal beceri eksikliği ve düşük benlik saygısı ile ilgili sonuçlar vermektedir (Zirt, 2005). Amerika'da Faraone ve arkadaşları tarafından (2005) yapılan bir araştırmada toplumun $\%$ 2,9'unda DEHB olduğu gözlenmiştir.
Biederman (2006) dikkat eksikliğinin çalışan ve iş yerinde maliyetleri üzerine yaptığı araştırmada DEHB ölçeğinden yüksek puan alan 261 kişinin konsantre olmalarının \%33; düşük puan alan 361 kişinin \%59 olduğunu gözlemiştir. DEHB'den yüksek puan alanlarda $\% 74$, olmayanlarda $\% 52$ işe uzun süre odaklanamama sorunu gözlenmiştir. İş yerinde organize olma DEHB yüksek puan alanlarda \%46, almayanlarda \%20; işyerinde kuralları takip etme zorluğu DEHB yüksek puan alanlarda \%39, almayanlarda \%69, işyerinde yükselmek için ilgi DEHB yüksek puan alanlarda $\% 5$, almayanlarda \%11; iş değiştirme sıklığı DEHB yüksek puan alanlarda \%31 almayanlarda \% 45; sahip oldukları rahatsızlıktan dolayı iş kaybı ve işten ayrılma oranı DEHB yüksek puan alanlarda \% 5.4, almayanlarda \% 3.4 olarka ölçülmüş; DEHB yüksek puan alanlarda iş yerinden ve kariyerinden memnun olma düzeyi yalnızca \%22 çıkmıştır. DEHB yüksek puan alanlarda kişi başına iş verimliliği kaybı $\$ 8,900$ ile $\$ 15,400$ arasında değişmektedir.

Kessler'in 2005 yılında DEHB'nin iş performansına etkisi üzerine yaptığ 1 araştırmada $\% 4,4$ oranında DEHB'li olduğunu gözlemlemiştir. Araştırmayı 2399 yetişkin üzerinde yapmıştır. DEHB'li bireylerde, \%13,6 devamsızlık oranı tespit edilmiştir. İşe gelmemeye (abseenteism) bağlı kayıp $2,351 \$$, çalışma yaşamında var ol(ama)ma (bedeni işte ama ruhu değil durumu, presenteeism) \%21,6'dır. DEHB'ye bağlı iş kaybı ve satış kaybı $\$ 19,6$ milyon dolardir.

Kessler, 2008 yılında büyük üretim işletmelerinin DEHB'ye bağlı parasal kaybı ve işyerinde DEHB'nin yayılımı ile ilgili araştırmasında (DEHB) yüksek puan alanlarda iş performansında kaybın aylık \%8,5, almayanlarda bu oranın \%7,5; DEHB yüksek puan alanlarda iş yeri kazasının aylık $\% 13,9$, almayanlarda \% 7,2 olduğunu tespit etmiştir. DEHB yüksek puan alanlarda işyeri hastalığına bağlı izin alma oranı \%19,5, almayanlarda \%10,1, DEHB'ye bağlı yıllık iş performansı kaybı \$4.336'dir.

White ve Shah (2006), DEHB olan genç yetişkinlerin bu probleme sahip olmayanlara göre daha yaratıcı olduğunu yaptıkları araştırmada tespit etmişlerdir. DEHB olan kişilerin farklı düşünme tarzlarını tercih ettiklerini tespit eden, Eckerd Üniversitesi ve Michigan Üniversitesi'nde çalışmalar yapan White ve Shah, DEHB'li kişilerin fikir üretmekten hoşlandığını fakat sorumlulukları tamamlama konusunda başarılı olmadıklarını belirtmektedir. White ve Shah çalışmalarını 2006 yılından beri tekrar ettiklerini ve tüm sonuçlarda DEHB olan kişilerin standart yaratıcılık testlerinde daha iyi sonuç elde ettiğini söylemektedirler. 
White ve Shah (2006) tarafından yapılan çalışmada yarısı DEHB olan 60 üniversite öğrencisi mizah, müzik, görsel sanatlar, mutfak sanatları, buluş ve yazma gibi on ayrı alandaki yaratıcılıklarının başarı düzeylerini ölçen bir anketi tamamlamışlardır. DEHB olan kişilerin "farklı düşünme" laboratuvar ölçümlerinin daha iyi olduğunu bildiklerini, fakat bu durumlarını gerçek hayatta başarıya çevirip çevirmediklerini bilmediklerini ve bu çalışmayla da bunu yapabildiklerini belirtmektedirler. DEHB olanlar bu bozukluğa sahip olmayanlara göre daha yüksek puan almıştır.

White ve Shah (2006) tarafından yapılan başka bir ankette katılanların problem tanımlama ve yapılandırma, fikir üretme, problemi detaylandırma ve belirginleştirme, problemin çözümüne seçkin bir fikir ekleme gibi yaratıcılık tarzlarından hangisini tercih ettiği değerlendirilmiştir. DEHB olmayan katılımcılar açıklama ve fikir geliştirme tarzını tercih ederken, DEHB olan katılımcilar fikir üretmeyi tercih etmiştir. Araştırmacılar yaratıcılık tarzını bilmenin, DEHB olan kişilerin güçlü ve zayıf yönlerine uygun kariyer tanımlamasına yardımcı olabileceğini belirtmektedir (İkinci, 2012).

DEHB yakınmaları olan bir birey çoğu zaman benlik algısından uzak olduğu için "kendini yönetme" yeteneğinden de uzaktır. DEHB'li bireyler hedef belirleme ve bu hedeflere ulaşmak amacıyla motive olma, hedefin gerçekleşme oranını ölçümleyebilmek amacıyla değerlendirme ve geri bildirim yapabilme yeteneklerinden yoksundurlar. DEHB'li bireylerin yakınmaları arasında yer alan motivasyon eksikliği, tekrarlayan işlerde devamsızlık ve vazgeçme, başladığı işe devam edememe gibi belirgin yakınmaları DEHB'li bireylerin örgütsel yaşantıda performans düşüklüğü ile karşılaşmalarına neden olmaktadır. $\mathrm{Bu}$ durum DEHB'li bireylerin performans düşüklüğünün işte başarısızlık olarak geri dönmesine neden olabilmektedir. DEHB'li bireylerin kendi kendine performansını değerlendiremiyor olması çoğu zaman performanslarının ölçülmesinde güçlüklere neden olabilmektedir. Bu noktada örgütler için önemli bir kaynak niteliğinde olan performans değerlendirme sonuçları sağlıklı olarak elde edilememektedir (Altınay \& Alamur,2015).

DEHB'li çalışanlarda en önemli sorunlarından biri de işten ayrılma niyetidir. Çalışanın, işten ayrılma niyetini etkileyen devam bağlılığı çalışanın örgütten ayrılıp ayrılmaması sonucu katlanmak zorunda kalacağı maliyetlerle ilişkili bir kavramdır. Çalışanların, devam bağlılıkları örgüte yapmış oldukları yatırımlar ve bu yatırımlara vermiş oldukları değer ile ilişkilidir. Ancak, çalışanların devam bağlılığını etkileyen faktörler yalnızca yatırımlar veya işten ayrılması durumunda katlanmak zorunda kalacağı maliyetler ile ilişkili değildir. Çalışanın başka örgütlerde iş bulma alternatiflerinin az olması veya az olduğu yönündeki genel inancı da çalışanların devam bağlılıklarını etkilemektedir (Meyer \& Allen, 1997: 77-82).

Normatif bağlılık hisleri kuvvetli çalışanların örgütsel amaç ve hedefleri gerçekleştirecek yönde davranışlar sergilemelerinin veya örgütün üyesi olarak kalma yönünde irade göstermelerinin nedeni çalışanların bu şekilde davranmaları gerektiği yönündeki inanışları ve yükümlülük duygularıdır. Çalışanların örgüte karşı yükümlülükleri olduğuna inanmaları, kendilerini örgütte kalmaya mecbur hissetmelerine sebep olmaktadır. Buradaki mecburiyet kavramı devam bağlılığında olduğu gibi çıkara değil ahlaki duygulara ve minnet borcuna dayanmaktadir. Ancak, DEHB'li bir bireyin en belirgin yakınmaları olan sürekli tekrarlayan işlere konsantre olamama ve tecrübe edinebilecek kadar uzun bir süre aynı işe odaklanamama gibi yakınmalar DEHB'li bireylerde işgücü devir oranının yükselmesi şeklinde sonuçlanmaktadır (Altınay \& Alamur, 2015) .

\section{ARAŞTIRMA VERİ VE ANALIZLLRII}

\subsection{Araştırmanın Amacı ve Sorunsalı}

Literatürde, çalışanlarda ve yöneticilerde dikkat eksikliği ve hiperaktiviteyi nitel veya nicel analiz yöntemiyle araştıran sınırlı sayıda çalışma mevcuttur. Özellikle ulusal yazında, iş hayatında çalışanlarda dikkat eksikliğinin ve hiperaktivitenin varlığını ve düzeyini inceleyen çalışmalar konusunda bir boşluk olduğu görülmektedir. Araştırma sonuçlarının akademisyen ve uygulamacılara çalışanlarda dikkat eksikliği ve hiperaktivitenin rolü ve önemi konusunda güncel bilgi sağlaması, ileride yapılacak araştırmalarda farklı boyutların ve ilişkilerin araştırılmasına katkı sağlaması beklenmektedir. Araştırmanın amacı, iş yaşamında çalışanların arasında hiperaktivite ve dikkat eksikliği olanların varlığını yüzde olarak tespit etmektir. Araştırmanın alt amaçları ise aşağıda sıralanmıştır.

a) İşyerlerinde DEHB'li olan çalışanların oranı ne kadardır?

b) Çalışanların pozisyonlarına göre DEHB değişmekte midir? Farklılıklar var mıdır? 
Tablo 1: Araştrmaya Ilişkin Demografik Değişkenler

\begin{tabular}{|c|c|c|c|c|c|}
\hline \multicolumn{3}{|c|}{ YAŞ DEGIȘKENI } & \multicolumn{3}{|c|}{ ÇALIȘMA SURESI } \\
\hline & $F$ & $\%$ & & $\mathrm{f}$ & $\%$ \\
\hline $17-19$ & 43 & 8,6 & \multirow{6}{*}{$\begin{array}{l}1-5 \text { yl } \\
6-10 \text { yll } \\
11-15 \text { yll } \\
16-20 \text { yl } \\
21 \text { yll ve } \\
\text { üzeri }\end{array}$} & 269 & 53,8 \\
\hline $20-25$ & 172 & 34,4 & & 77 & 15,4 \\
\hline $26-30$ & 84 & 16,8 & & 65 & 13,0 \\
\hline $31-35$ & 77 & 15,4 & & 53 & 10,6 \\
\hline $36-40$ & 68 & 13,6 & & 36 & 7,2 \\
\hline $\begin{array}{l}41-45 \\
46 \text { ve üzeri }\end{array}$ & $\begin{array}{l}35 \\
21\end{array}$ & $\begin{array}{l}7,0 \\
4,2\end{array}$ & & & \\
\hline \multicolumn{3}{|c|}{ MEDENI DURUM } & \multicolumn{3}{|c|}{ POZISYON DURUMU } \\
\hline Evli & 254 & 50,8 & Çalıșan & 324 & 64,8 \\
\hline Bekâr & 246 & 49,2 & Yönetici & 176 & 35,2 \\
\hline \multicolumn{3}{|c|}{ CINSIYET } & \multicolumn{3}{|c|}{ SEKTOR } \\
\hline Kadm & 245 & 49,0 & Kamu & 238 & 47,6 \\
\hline Erkek & 255 & 51,0 & Ozel & 262 & 52,4 \\
\hline \multicolumn{3}{|c|}{ EGITIM DUZEYI } & \multicolumn{3}{|c|}{ MESLEK } \\
\hline Lise & 27 & 5,4 & Akademisyen & 137 & 27,4 \\
\hline Universite & 276 & 55,2 & $\begin{array}{l}\text { Stajyer } \\
\text { ögrenci }\end{array}$ & 88 & 17,6 \\
\hline Master & 99 & 19,8 & Memur & 55 & 11,0 \\
\hline \multirow[t]{13}{*}{ Doktora } & \multirow[t]{13}{*}{98} & \multirow[t]{13}{*}{19,6} & $\begin{array}{l}\text { deneyimi } \\
\text { olan ögrenci }\end{array}$ & 49 & 9,8 \\
\hline & & & $\begin{array}{l}\text { Müdür ve } \\
\text { Müdür }\end{array}$ & 49 & 9,8 \\
\hline & & & $\begin{array}{l}\text { Yardimcisı } \\
\text { Yaritam }\end{array}$ & & \\
\hline & & & $\begin{array}{l}\text { zamanlı } \\
\text { çalı̨̧an } \\
\text { öğrenci }\end{array}$ & 28 & 5,6 \\
\hline & & & Işçi & 28 & 5,6 \\
\hline & & & Selreter & 8 & 1,6 \\
\hline & & & Doktor & 5 & 1,0 \\
\hline & & & Bankacı & 15 & 3,0 \\
\hline & & & Mühendis & 8 & 1,6 \\
\hline & & & Oğretmen & 14 & 2,8 \\
\hline & & & Hemģire & 3 & 0,6 \\
\hline & & & Diğer & 9 & 1,8 \\
\hline & & & $\begin{array}{l}\text { Laboratuvar } \\
\text { Teknisyeni }\end{array}$ & 4 & 0,8 \\
\hline TOPLAM & $\mathbf{5 0 0}$ & 100 & & $\mathbf{5 0 0}$ & 100 \\
\hline
\end{tabular}

\subsection{Araştırmanın Yöntemi}

Araştırmada veri toplama tekniği olarak anket tekniğinden yararlanılmıştır. Anket soruları farklı görevlerde ve mesleklerde yer alan 500 çalışana online olarak (https://docs.google.com/forms/d/1dUSn56wh3TW zSp8pYY8jHEsWchXfuDOlEqxz2FEjcu0/viewfor $\mathrm{m \# start=openform)} \mathrm{uygulanmıştır.} \mathrm{Elde} \mathrm{edilen}$ veriler SPSS istatistiki programı kullanılarak analiz edilmiştir. Verilerin analizinde; güvenilirlik analizi ve faktör analizinin yanı sıra ankete katılanların iş yerinde dikkat eksikliği hiperaktivite düzeylerinin yönetici ve çalışan olma durumuna göre farklılığını tespit amacıyla $t$ testi yapılmıştır.

\subsection{Araştırmada Kullanılan Ölçekler}

Araştırmada Doğan, Öncü, Varol-Saraçoğlu, ve Küçükgöncü'nün 2009 yılında yapmış oldukları Dünya Sağlık Örgütü'nün Erişkin Dikkat Eksikliği Hiperaktivite Bozukluğu Kendi Bildirim Ölçeğinin (ASRS) Türkçe formu kullanılmıştır. Dikkat eksikliği ve hiperaktiviteye yönelik 5'li Likert tipi (5: Çok sık, 4: Nadiren, 3: Bazen, 2: Sık, 1: Asla) ölçek ile hazırlanan 18 ifade yer almaktadır. Yanıtlar artan sıklıkla eşleşecek şekilde 0-5 
Tablo 2: Güvenilirlik Analizi Sonuçları

\begin{tabular}{lcc}
\hline Değişkenler & $\begin{array}{c}\text { Soru } \\
\text { Sayısı }\end{array}$ & $\begin{array}{c}\text { Cronbach Alfa } \\
(\boldsymbol{\alpha})\end{array}$ \\
\hline Dikkat Eksikliği & 9 & .832 \\
Hiperaktivite & 9 & .833 \\
\hline
\end{tabular}

arasında puanlanmaktadır. Her maddenin puanı toplanarak toplam değere ulaşılır. Ölçeğin "dikkat eksikliği" ve "hiperaktivite / dürtüsellik" olmak üzere, her biri dokuz sorudan oluşan iki alt ölçeği vardır. İki alt ölçeğin toplamından 70-90 puan ve üzerinde alanların "yüksek olasılıkla DEHB" olduğu, bildirilmiştir (Öyekçin \& Şahin, 2011; Doğan vd., 2009).

Dünya Sağlık Örgütü’nün Erişkin Dikkat Eksikliği ve Hiperaktivite Bozukluğu Kendi Bildirim Ölçeği (ASRS) birçok dile çevrilmiş uluslararası epidemiyolojik çalışmalarda yaygın olarak kullanılmış bir tarama aracıdır. ASRS'nin Türkçe formunun geçerlilik ve güvenilirlik çalışmaları Doğan ve arkadaşları tarafindan 2009 yılında tamamlanmıştır. Doğan ve arkadaşlarının (2009) güvenilirlik analizinde ölçeğin iç tutarlılığ Cronbach alfa değeri $(0,88)$ olarak hesaplanmıştır. Alt ölçekler için hesaplanan Cronbach alfa değeri de 'dikkat eksikliği' için 0.82, 'hiperaktivite / dürtüsellik' için 0,78 olmak üzere yüksek bulunmuştur. İki hafta sonra 50 katılımcıya uygulanan test-tekrar test güvenilirliği için Cronbach alfa değeri 0,81 olarak bulunmuştur. Test-tekrar test tutarlılığı için iki testin toplam ve alt ölçekleri arasındaki korelasyon anlamlı çıkmıştır.

\subsection{Araştırmanın Evren ve Örneklemi}

Araştırmanın evrenini internet ortamında ulaşılan farklı meslek gruplarından çalışanlar oluşturmaktadır. Örneklem ise, bu çalışanlar arasından rastgele seçilen 500 kişidir. Katılımcıların mesleki açıdan dağılımı incelendiğinde ilk sırada $\% 27,4$ ile akademisyenlerin yer aldıkları görülmektedir. İkinci sırada \% 17,6 ile stajyer öğrenciler ve üçüncü sırada da \%11 ile memurlar yer almaktadir.

\subsection{Verilerin Analizi}

$\mathrm{Bu}$ çalışmada DEHB'nin öncelikle yüzde olarak varlığı tespit edilmiştir. İkinci olarak aritmetik ortalamalarla hiperaktivite ve dikkat eksikliği soruları analiz edilmiştir. Üçüncü olarak, t testi ile yönetici ve çalışan olma durumuna göre farklılık olup olmadığ 1 test edilmiştir.

\subsection{Araştırmanın Örneklemine İlişkin Bulgular}

Araştırmaya katılanların demografik bilgileri Tablo 1 'de yer almaktadır. Araştırmaya katılan örneklemin \%50,8'i evli, \%49,2'si bekârdır. Katılımcıların cinsiyet dağılımına bakıldığında \%51'i erkek, \%49'u kadındır. Örneklem yaş değişkeni açısından incelendiğinde katılımcılar $\% 34,4$ oranıyla 20-25 yaş arasında yer almaktadır. Başka bir ifadeyle araştırmaya katılanların (20-30 yaş arası \%51,2) oldukça genç olduğu görülmektedir. Anketi cevaplayanların mesleki deneyim süreleri incelendiğinde; \%53,8'inin 1 ile 5 yıl arasında iş hayatında oldukları tespit edilmiştir. Araştırmaya katılanların \%64,8'si yönetici, \%35,2'si çalışan konumundadır. Eğitim seviyesi açısından incelendiğinde katılımcıların ağırlıklı olarak üniversite $(\% 55,2)$ ve üzeri $(\% 39,4)$ eğitimli oldukları görülmektedir. Ayrıca araştırmaya katılanların \% 47,6's1 kamuda, \%52,4'ü özel sektörde çalışmaktadır. Katılımcıların mesleki açıdan dağılımı incelendiğinde ilk sırada \%27,4 ile akademisyenlerin yer aldıkları görülmektedir. İkinci sırada \% 17,6 ile stajyer öğrenciler ve üçüncü sırada da $\% 11$ ile memurlar yer almaktadır.

\subsection{Araştırmada Kullanılan Ölçeklere Yönelik Bulgular}

Doğan ve arkadaşlarının (2009) yaptığı güvenilirlik analizinde ölçeğin iç tutarlılığ Cronbach alfa değeri $(0,88)$ hesaplanarak gösterilmiştir. Alt ölçekler için hesaplanan Cronbach alfa değeri de 'dikkat eksikliği' için 0,82, 'hiperaktivite / dürtüsellik' için 0,78 olmak üzere ortaya çıkmıştır (Doğan vd., 2009: 80). Araştırmamızda güvenilirlik analizinde her bir değişkenin Cronbach alfa katsayılarına bakılmış ve Tablo 2'de verilmiştir.

Alan yazında iç tutarlılık katsayısı ,70'in üzerinde hesaplanan değerler iyi olarak kabul edilmekte (Altunışık vd., 2005; Tavşancıl, 2002) ve 1.00'e yaklaştıkça çok iyi olarak görülmektedir (Ural \& Kılıç, 2006). Alan yazına göre hesaplanan iç tutarlık katsayılarının iyi oldukları söylenebilir.

\subsection{Analiz Sonucunda Elde Edilen Bulgular}

Tablo 3'te araştırmaya katılanların dikkat eksikliği ve hiperaktivite ile ilgili ifadelere yönelik ortalamaları ve Cronbach alfa katsayıları verilmiştir.

$(\mathrm{KMO}=0,869$; Barlett Küresellik Testi $=3579,810$; $\mathrm{p}<, 000)$ açıklanan toplam varyans \%44.58 olup faktör analizinde F1 varyansın \%22.29'unu, F2 ise \%22.30'unu açıklamaktadır. Bu iki faktörün kendi içinde güvenilirliğine de bakılmış, F1 için Cronbach 
Tablo 3: Ifadelere Ait Aritmetik Ortalama ve Alfa Değerleri

\begin{tabular}{|c|c|c|}
\hline DIKKAT EKSIKLIGI & $\begin{array}{l}\text { Arit. } \\
\text { Ort. }\end{array}$ & $\begin{array}{c}\text { Cronbach' } \\
\text { s Alpha }\end{array}$ \\
\hline $\begin{array}{l}\text { 1. Uzerinde çalıştğımız bir işin/projenin son ayrıntılarını toparlayıp projeyi tamamlamakta sorun yaşar } \\
\text { mısınız? }\end{array}$ & 2,24 & ,839 \\
\hline $\begin{array}{l}\text { 2. Organizasyon gerektiren bir iş yapmanız zorunlu olduğunda işlerinizi sıraya koymakta ne sılklkla } \\
\text { zorluk yaşarsınız? }\end{array}$ & 2,15 &, 840 \\
\hline 3. Yükümlülüklerinizi ve randevularımız hatırlamalta ne sıklıkla sorun yaşarsınız? & 1,90 &, 839 \\
\hline $\begin{array}{l}\text { 4. Çok fazla düşünmeyi ve konsantrasyonu gerektiren bir iş yapmanız gerekiyorsa ne sılklkla } \\
\text { başlamaktan kaçınır ya da geciktirirsiniz? }\end{array}$ & 2,36 &, 837 \\
\hline 7. Sıkıcı veya zor bir proje üzerinde çalışmanız gerektiğinde, ne sılklıla dikkatsizce hatalar yaparsınız? & 2,56 &, 835 \\
\hline 8. Monoton veya tekrarlayıcı bir iş yaparken ne sılklıkla dilkkatinizi sürdürmekte güçlük çekersiniz? & 2,83 &, 833 \\
\hline $\begin{array}{l}\text { 9. Doğrudan sizinle konuşuyor bile olsalar, insanların size söylediklerine yoğunlaşmakta ve dinlemekte } \\
\text { ne sıklıkla güçlïk yaşarsınız? }\end{array}$ & 2,34 &, 833 \\
\hline $\begin{array}{l}\text { 10. Evde veya işte eşyalan bulmakta ya da nereye koyduğunuzu hatırlamakta ne sıklıkla güçlük } \\
\text { yaşarsınız? }\end{array}$ & 2,49 &, 835 \\
\hline 11. Etrafınızdaki hareketlilik ve gürültï ne sıklıkla dilkkatinizi dağıtır? & 3,08 &, 841 \\
\hline \multicolumn{3}{|l|}{ HIPERAKTIVITE } \\
\hline $\begin{array}{l}\text { 5. Uzun bir süre oturmanız gerektiğinde, ne sıkikla huzursuzlaşır, kıpırdanır ya da el ve ayaklarınızı } \\
\text { kupırdatırsınız? }\end{array}$ & 3,15 &, 835 \\
\hline 6. Ne sılklıkla kendinizi aşın aktif ve sanki motor taklmıs gibi bir şeyler yapmak zorunda hissedersiniz? & 3,10 &, 842 \\
\hline $\begin{array}{l}\text { 12. Orada oturmanız beklendiğinde, bir toplantı veya benzer durumda ne sıllıkla yerinizden } \\
\text { kalkarsınız? }\end{array}$ & 2,23 &, 834 \\
\hline 13. Ne sılklıkla kendinizi huzursuz, kupır kupır hissedersiniz? & 2,82 &, 832 \\
\hline 14. Kendinize ait boş zamanınız olduğunda ne sılklıla gevşemekte ve rahatlamakta güçlük çekersiniz? & 2,41 & 842 \\
\hline 15. Sosyal ortamlarda bulunduğunuzda, ne sılklıkla kendinizi çok konuşurken yakalarsınız? & 3,01 &, 842 \\
\hline $\begin{array}{l}\text { 16. Bir sohbet ya da görüşmede, ne sılklıla karşınızdaki kişi cümlesini bitirmeden onun cümlesini } \\
\text { bitirdiğinizi fark edersiniz? }\end{array}$ & 2,65 &, 837 \\
\hline 17. Sıraya girmek gerektiğinde, ne sıklıkla sıranızın gelmesini beklemekte güçlük çekersiniz? & 2,82 &, 836 \\
\hline 18. Başka bir işle meşgul olduklarında araya girip diğer insanları engeller misiniz? & 2,08 &, 838 \\
\hline
\end{tabular}

$\alpha=0.832, \quad$ F2 için Cronbach $\alpha=0.833$ olarak hesaplanmıştır.

Tablo 5'te araştırmada kullanılan soru setinde yer alan dikkat eksikliği ve hiperaktivite ölçüm puanları görülmektedir.

Tablo 6'ya göre, araştırmaya katılanların DEHB ölçeğinin alt boyut puanlarının ortalamaları incelendiğinde dikkat eksikliği alt boyut ortalamasının 2,44; hiperaktivite alt boyut ortalamasının 2,70 puanla orta düzeyde olduğu görülmektedir.

Tablo 7'ye göre, araştırmaya katılanların DEHB ölçeğinin alt boyut puanlarının toplamları incelendiğinde, dikkat eksikliği ve hiperaktivite alt boyut toplam puanlarının en yüksek 18 soru için 90 puan üzerinden 70-90 aralığında puan alanlar DEHB olanlar olarak tespit edilen 12 kişi ile $\% 2,4$ olarak bulunmuştur.
Araştırmaya katılanların DEHB ölçeğinin yönetici ve çalışan olma değişkenine göre (Tablo 8) anlamlı bir farklılık gösterip göstermediğini belirlemek amaciyla yapılan t-testi sonucunda, yönetici ve çalışanların aritmetik ortalamalarının arasındaki fark, istatistiksel olarak anlamlı bulunmamıştır ( $\mathrm{t}=$ ,590, 232; p>.05).

\section{SONUÇ VE ÖNERILER}

Araştırma sonucunda, çalışanların \%2,4'ünde DEHB olduğu sonucuna ulaşılmıştır. Sonuç olarak; DEHB yönetici ve çalışan olma değişkenine göre anlamlı bir farklılık göstermemektedir. Araştırma sonuçlarını dünyada yapılan diğer çalışmalarla kıyasla amacıyla Kessler'in 2005 y1lında DEHB'nin iş performansına etkisi üzerine yaptığı araştırma dikkate alındığında, söz konusu araştırmada katılımcıların \% 4,4 oranında DEHB'li olduğu gözlemlenmiştir. Amerika'da Faraone ve arkadaşları tarafından (2005) yapılan diğer bir 
Tablo 4: Faktör Analizi

\begin{tabular}{|c|c|c|}
\hline DİKKAT EKSİKLİĠi & $\begin{array}{l}\text { Faktörler, } \\
\text { yükleri ve } \\
\text { güvenilirlikleri }\end{array}$ & $\begin{array}{c}\text { Cronbach' } \\
\text { s Alpha }\end{array}$ \\
\hline $\begin{array}{l}\text { 1. Uzerinde çalıştığmuz bir ig̣injprojenin son ayrnntlarım toparlayıp projeyi tamamlamakta } \\
\text { sorun yaģar mısını?? }\end{array}$ & 0.64 & \multirow{9}{*}{, 832} \\
\hline $\begin{array}{l}\text { 2. Organizasyon gerektiren bir iş yapmanız zorumlu olduğunda iģlerinizi sıraya koymakta ne } \\
\text { sıllkkla zorluk yaşarsunzz? }\end{array}$ & 0.61 & \\
\hline $\begin{array}{l}\text { 3. Yükümlülüklerinizi ve randevularmız haturlamakta ne stkllkla sorun yagarsmuz? } \\
\text { 4. Çok fazla dügünmeyi ve konsantrasyonu gerehtiren bir iş yapmanız gerekiyorsa ne sıklıkla }\end{array}$ & $\begin{array}{l}0.71 \\
0.65\end{array}$ & \\
\hline başlamaktan kaçınır ya da geciktirirsiniz? & & \\
\hline $\begin{array}{l}\text { 7. Sılacı veya zor bir proje ũzerinde çalışmanız gerehtiǧinde, ne sıklıkla dikkatsizce hatalar } \\
\text { yaparsını? }\end{array}$ & 0.60 & \\
\hline $\begin{array}{l}\text { 8. Monoton veya tekrarlayıcı bir iş yaparken ne sıklıkla dikkatinizi sürdürmekte guüçǚk } \\
\text { çekersiniz? }\end{array}$ & 0.50 & \\
\hline $\begin{array}{l}\text { 9. Doğrudan sizinle konuşuyor bile olsalar, insanlarm size söylediklerine yoğunlaşmakta ve } \\
\text { dinlemekte ne sıklıkla güçlük yạ̧arsımız? }\end{array}$ & 0.47 & \\
\hline $\begin{array}{l}\text { 10. Evde veya işte eşyalan bulmakta ya da nereye koyduğunuzu haturlamakta ne siklıkla } \\
\text { gūçlük yaģarsmuz? }\end{array}$ & 0.46 & \\
\hline 11. Etrafinızdaki hareketlilik ve gürültü ne sılklkla dikkatinizi dağıtır? & 0.45 & \\
\hline \multicolumn{3}{|l|}{ HIPERAKTIVITE } \\
\hline $\begin{array}{l}\text { 5. Uzun bir süre oturmanız gerehtiğinde, ne sılklkla huzurguzlaģır, kapırdamır ya da el ve } \\
\text { ayaklarmızı kpurdatırsını? }\end{array}$ & 0.73 & \multirow{7}{*}{833} \\
\hline $\begin{array}{l}\text { 6. Ne sıklıkla kendinizi aşın altif ve sanki motor takılmı̣ gibi bir ģeyler yapmak zorunda } \\
\text { hissedersiniz? }\end{array}$ & 0.63 & \\
\hline $\begin{array}{l}\text { 12. Orada oturmanız beklendiğinde, bir toplant veya benzer durumda ne sikllkla yerinizden } \\
\text { kalkarsinz? }\end{array}$ & 0.59 & \\
\hline $\begin{array}{l}\text { 13. Ne slkllkla kendinizi huzursuz, kapur kupur hissedersiniz? } \\
\text { 14. Kendinize ait boş zamanınız olduğunda ne sıllıkla gevğemekte ve rahatlamalta güçlük } \\
\text { çekersiniz? }\end{array}$ & $\begin{array}{l}0.64 \\
0.53\end{array}$ & \\
\hline $\begin{array}{l}\text { 15. Sosyal ortamlarda bulunduğunuzda, ne sıklıkla kendinizi çok konuş̧urken yakalarsını? } \\
\text { 16. Bir sohbet ya da görüşmede, ne sıklıkla karģınıdaki kiģ̣i cümlesini bitimeden onun } \\
\text { cümlesini bitirdiğinizi fark edersiniz? }\end{array}$ & $\begin{array}{l}0.55 \\
0.44\end{array}$ & \\
\hline $\begin{array}{l}\text { 17. Suraya girmek gerehtiǧinde, ne slklıkla sıramuzn gelmesini beklemekte güçlük } \\
\text { çekersiniz? }\end{array}$ & 0.45 & \\
\hline 18. Baģka bir işle meğgul olduklannda araya girip diğer insanlan engeller misiniz? & 0.44 & \\
\hline
\end{tabular}

araştırmada ise \%2,9'unun DEHB'li olduğu gözlenmiştir. "Dikkat Eksikliği ve Hiperaktivite Bozukluğu" kavram olarak insan davranışlarını bütünüyle değiştiren bir psikolojik süreçtir.

Günümüzde pek çok çalışan DEHB'li olarak yaşadığı bazı psikolojik rahatsızlıkları gizlemeye ve görmezden gelmeye çalışmaktadır. Daha da önemlisi pek çok insan bir rahatsızlık içinde olduğunun farkındalığı içerisinde bile değildir. $\mathrm{Bu}$ durum sosyal hayatın her alanında aktif olan/olmak zorunda olan bireylerin sosyal ilişkiler, aile içi ilişkiler ve iş ilişkileri içerisinde başarısızlıklarla dolu bir hayat geçirmelerine neden olmaktadır. $\mathrm{Bu}$ durum bireyler açısından, maddi ve manevi büyük maliyetlere yol açmaktadır. İş yerinde özellikle bu DEHB'li çalışanların, dikkat süresinin kısalığ yaptıkları işin kalitesini ve çıktılarını etkileyecektir. $\mathrm{Bu}$ kişiler daha az önemli işleri yaparken dikkatlerinin dağıldığını ve yapmaları gereken önemli işleri ise bir türlü tamamlayamadıklarını ifade ettiklerinden iş yerinde insan kaynakları açısından gözlenmeleri ve analiz edilmeleri gerekmektedir. İş yerinde özellikle bu DEHB'li çalışanlar; birçok işi aynı anda yapmaları gerektiğinde hangi işi öncelikli yapmaları gerektiğine karar veremezler, karar verebildikleri durumda ise işi sürdürebilmeleri zordur, bu durumu 
Tablo 5: İ̧̧ Yerinde Dikkat Eksikliği Hiperaktivite Ölçeği Aralık Katsayısına Bağlı Olarak Gruplandirma

\begin{tabular}{cc}
\hline Puan Aralıklar & Dikkat Eksikliği Hiperaktivite \\
\hline $1,00-1,80$ & Çok Düşük \\
$1,81-2,60$ & Düşük \\
$2,61-3,40$ & Orta \\
$3,41-4,20$ & Yüksek \\
$4,21-5,00$ & Çok Yükssek \\
\hline
\end{tabular}

Tablo 6: Araştırmaya Katılanların DEHB Puanlarının Ortalamaları

\begin{tabular}{lccccc}
\hline Boyutlar & N & Min. & Mak. & Ort. & St. S. \\
\hline Dikkat eksikliği & 500 & 1,00 & 4,56 & 2,44 & 0,57 \\
Hiperaktivite & 500 & 1,00 & 4,78 & 2,70 & 0,61 \\
\hline
\end{tabular}

Tablo 7: Araştırmaya Katılanların DEHB Toplam Puanlarına Göre Ayrılması

\begin{tabular}{lcc}
\hline Boyutlar & f & $\%$ \\
\hline DEHB olanlar & 12 & 2,4 \\
DEHB olmayanlar & 488 & 97,6 \\
\hline & 500 & 100 \\
\hline
\end{tabular}

Tablo 8: DEHB Düzeylerinin Yönetici ve Çalışan Olma Duruma Göre Farklılı̆̆ı

\begin{tabular}{|c|c|c|c|c|c|c|}
\hline Boyutlar & & $\overline{\mathbf{n}}$ & $\bar{X}$ & St. S. & $\mathbf{t}$ & $\mathbf{p}$ \\
\hline \multirow{2}{*}{ Dikkat eksikliği } & Çalışan & 324 & 2,43 & 57 & \multirow{2}{*}{,- 590} & \multirow{2}{*}{, 82} \\
\hline & Yönetici & 176 & 2,46 &, 57 & & \\
\hline \multirow{2}{*}{ Hiperaktivite } & Çalışan & 324 & 2,70 & 62 & \multirow{2}{*}{, 232} & \multirow{2}{*}{, 56} \\
\hline & Yönetici & 176 & 2,69 &, 59 & & \\
\hline
\end{tabular}

gözlemleyen yöneticilerin bu çalışanları kazanmaları ve önlem almaları gerekmektedir.

Araştırmamızın en önemli kısıtı online yapmamız ve birkaç sektörle sınırlı kalmasıdır. Çalışmayı bu bağlamda farklı sektörlerde yapmak faydalı olacaktır. Konuya ilişkin olarak DEHB'li çalışanlara yönelik önerilerimiz:

- Aklınıza gelen düşünceleri not edin ve üzerinde düşününüz. Yazdıklarınızı ne şekilde söylemenin uygun olduğunu düşününüz;

- Plan yapmadan birçok işe birden başliyor iseniz, iyi plan yapan bir takım oluşturunuz. Enerjinizi ve heyecanınızı olumlu şekilde yönlendiriniz. Toplantılarda not alınız. Bu şekilde ilgili görünürsünüz ama sıkıldığınız anlaşılmaz ve dikkatiniz artar.

- Gününüzü planlarken enerjinizi olumlu olarak programınıza dahil ediniz, örneğin toplantıya giderken uzun yolu yürümek, merdivenleri çıkmak gibi, hareket gerektiren ve enerjinizi boşaltabileceğiniz işler arayınız.

- Hafıza ile ilgili sıkıntılar yaşıyorsanız gün içinde ajandanızı sık sık kontrol etme alışkanlığ geliştiriniz; yapacağınız telefon konuşmaları, toplantı için ayrılmanız gereken zamanları hatırlatmak için çalar saat ve not defteri kullanınız. 
- Sikılacağınız şeyleri günün enerjik olduğunuz anlarında yapınız, yorulduğunuz anlara ertelemeyiniz;

Bundan sonra bu konuda çalışma yapacak olan araştırmacılara, iş yerinde DEHB'li çalışanlar ve motivasyon düzeyleri, performans düzeyleri, iş tatmin düzeyleri, DEHB'li çalışanların başarılı oldukları alanlar ve iş yaşamına finansal açıdan etkileri üzerine araştırma yapmaları önerilmektedir.

\section{KAYNAKÇA}

Altınay A., \& Alamur B., (2015). Dikkat eksikliği ve Hiperaktivite Bozukluğu. İçinde Ö. D. Ergun, (Ed.) Örgütsel Davranışta Güncel Konular (Genişletilmiş 3. Bask1). Bursa: Ekin Yayınevi.

Altunışık, R., Coşkun, R., Bayraktaroğlu, S. \& Yıldırım, E. (2005). Sosyal bilimlerde araștırma yöntemleri: SPSS uygulamal (4. baskı). Sakarya: Sakarya Kitabevi.

Biederman, J. \& Faraone, S. V. (2006). The effects of attention-deficit / hyperactivity disorder on employment and household income. Medscape General Medicine, 8(3), 1-9.

Brown, E. T. (2009). Dikkat eksikliği bozukluğu: Çocuklarda ve yetişkinlerde odaklanamayan zihin. (E. Çetintaş Sönmez, Çev.) Ankara: ODTU Yayıncilik.

Doğan, S., Öncü, B., Varol-Saraçoğlu, G. \& Küçükgöncü, S. (2009). Erişkin dikkat eksikliği hiperaktivite bozukluğu kendi bildirim ölçeği (ASRS-v1. 1): Türkçe formunun geçerlilik ve güvenilirliği. Anadolu Psikiyatri Dergisi, 10(2), 77-87.

Faraone S. V, \& Biederman J. (2005). What is the prevalence of adult attention deficit/hyperactivity disorder? Results of a population screen of 966 adults. Journal of Attention Disorders, 9, 384-391.

Faraone, S. V., Sergeant, J., Gillberg, C. \& Biederman, J. (2003). The worldwide prevalence of ADHD: is it an American condition?. World Psychiatry, 2(2), 104113

Güçlü, O. \& Erkıran, M. (2005). Dikkat eksikliği hiperaktivite bozukluğu tanısı alan çocukların ebeveynlerinde kişilik bozuklukları. Klinik Psikiyatri, 8, 18-23.

İkinci, Ö. (2012). Dikkat eksikliği ve hiperaktivite bozukluğu olan kişilerde yüksek yaratıcilık. http://www.biltek.tubitak.gov.tr/haberler/tip/s521_4.p df, Erişim tarihi: 30.03.2014.

Kessler R. C., Adler L. \& Ames M. (2005). The prevalence and effects of adult attention deficit / hyperactivity disorder on work performance in a nationally representative sample of workers. Journal of Occupational and Environmental Medicine, 47, $565-572$.

Kessler, R. C. \& Üstün, T. B. (2004). The world mental health (WMH) survey initiative version of the world health organization (WHO) composite international diagnostic interview (CIDI). International Journal of Methods in Psychiatric Research, 13(2), 93-121.

Kessler, R. C., Hwang, I., LaBrie, R., Petukhova, M., Sampson, N.A., Winters, K.C. \&Shaffer, H.J. (2008). The prevalence and correlates of DSM-IV pathological gambling in the National Comorbidity Survey Replication. Psychological Medicine, 38(9), 1351-1360.

Kessler R. C. (2009). The prevalence and workplace costs of adult attention deficit hyperactivity disorder in a large manufacturing firm. Psychological Medicine, 39(1), 137-147. 
Kessler R. C. (2005). The World Health Organization adult ADHD self-report scale (ASRS): A short screening scale for use in the general population. Psychological Medicine, 35(2), 245-256.

Meyer, J. P. \& Allen, N. (1997). Commitment in the workplace, theory, research and application. London: Sage Publications.

Öyekçin, D. G. \& Şahin E. M., (2011). Erişkin dikkat eksikliği hiperaktivite bozukluğuna birinci basamak yaklaşım. Turkish Family Physcian, 2(4), 1-8.

Tavşancıl, E. (2002). Tutumların ölçülmesi ve SPSS ile veri analizi. Ankara: Nobel Yayın Dağıtım.

Tınaz, D. (2004). Ergen ve yetişkinde ADHD - Dikkat eksikliği ve hiperaktivite bozukluğu. Hasan Ali Yücel Ĕ̈itim Fakültesi Dergisi, 1, 195-206.

Ural, A. \& K1lıç, İ. (2006). Bilimsel araştırma süreci ve SPSS ile veri analizi. Ankara: Detay Yayınc1lık.

Weyandt, L. L. \& Dupaul, G. (2008). ADHD in college students: Developmental findings. Developmental Disabilities Research Reviews, 14, 311-319.

White H. \& Shah P. (2006) Uninhibited imaginations: Creativity in adults with attention-deficit / hyperactivity disorder. Personality and Individual Differences, 40, 1121-1131.

Yılmaz, M., Özdemir, G., Turgay, A. \& Çağl1, S. (2012). Üniversite öğrencilerinin Erişkin Dikkat Eksikliği Hiperaktivite Ölçeği'nin alt boyutları düzeylerinin çeşitli değişkenler açısından incelenmesi. International Journal of Human Sciences, 9(1), 627649.

Zirt, B. S. (2005). Adjustment, social skills, and selfesteem in college students with symptoms of ADHD. Journal of Attention Disorders, 8(3), 109-120. 